\title{
Sistem Pendukung Keputusan Penerima BOP Pendidikan Madrasah Dengan Metode Multi Criteria Decision Making (MCDM)
}

\author{
Akip Suhendar ${ }^{1}$, Epa Novia ${ }^{2}$ \\ ${ }^{12}$ Fakultas Teknologi Informasi - Universitas Serang Raya \\ Jln. Raya Serang - Cilegon km.5 Drangong - Banten, Indonesia. \\ ${ }^{1}$ akip.suhendaregmail.com \\ ${ }^{3}$ evanovial8@gmail.com
}

\begin{abstract}
Kementrian Agama kota Serang adalah salah satu lembaga yang berada dibawah Menteri Agama Republik Indonesia, Salah satu tugas utamanya adalah mengelola lembaga pendidikan islam yaitu madrasah diniyah, madrasah ibtida'iyah, madrasah pondok pesantren, dan juga pengelolaan dana bantuan operasional pendidikan. kurangnya akurasi antara kriteria dan persyaratan penerima BOP sehingga rentan terjadi manipulasi, oleh karena itu maka dibutuhkan sebuah sistem pendukung keputusan untuk memberikan rekomendasi terhadap penetapan penerima bantuan operasional pendidikan (BOP) yang akurat. Metode MCDM yang sesuai diterapkan untuk menyelesaikan permasalahan penetapan penerima BOP ini adalah metode Weighted Product Model (WPM) karena alasan kesederhanaan dan juga sesuai dengan proses pemilihan alternatif. Adapun Kriteria penerima bantuan operasional pendidikan (BOP) antara lain: minimal memiliki siswa 60 orang, memiliki izin operasional, bangunan fisik, minimal memiliki 4 kelas, minimal memiliki 4 orang pengajar, usia madrasah minimal 2 tahun, tidak sedang mendapatkan bantuan dari instansi lain. tujuan penelitian ini adalah menerapkan metode MCDM untuk membangun aplikasi sistem pendukung keputusan penentuan penerima BOP madrasah dan memudahkan bagian Kementrian Agama untuk menyeleksi calon penerima bantuan operasional pendidikan. pada penelitian ini menghasilkan sebuah sistem pendukung keputusan untuk memberikan rekomendasi terhadap penetapan penerima bantuan operasional pendidikan (BOP) madrasah, aplikasi ini dibangun dengan menggunakan Delphi 7 dan database MySql.
\end{abstract}

Kata kunci: Kememtrian Agama, kriteria penerimaan, SPK Bop madrasah.

\section{Pendahuluan}

Kementrian Agama kota Serang adalah salah satu lembaga yang berada dibawah Menteri Agama Republik Indonesia yang sampai saat ini belum memanfaatkan teknologi informasi dengan maksimal. Salah satu tugas utamanya adalah mengelola lembaga pendidikan islam yaitu madrasah diniyah, madrasah ibtida'iyah, madrasah pondok pesantren, dan juga pengelolaan dana bantuan operasional pendidikan. Dalam pengelolaan dana pendukung madrasah ada beberapa ketentuan yg diberikan yaitu bantuan operasional sekolah. (BOS), bantuan siswa miskin (BSM), bantuan operasional pendidikan (BOP). Untuk pengelolaan BOP disini masih dilakukan dengan cara yang belum menggunakan teknologi secara maksimal, tidak sesuai dengan yang diharapkan sehingga sering terjadi ketidak akuratan antara data penerima dengan persyaratan yang ada, proses seleksi madrasah penerima BOP membutuhkan waktu yang lama, kurangnya akurasi antara kriteria dan persyaratan penerima BOP sehingga rentan terjadi manipulasi, oleh karena itu maka dibutuhkan sebuah sistem pendukung keputusan untuk memberikan rekomendasi terhadap penetapan penerima bantuan operasional pendidikan (BOP) yang akurat. Metode MCDM yang sesuai diterapkan untuk menyelesaikan permasalahan penetapan penerima BOP ini adalah metode Weighted Product Model (WPM) karena alasan kesederhanaan dan juga sesuai dengan proses pemilihan alternatif. Adapun Kriteria penerima bantuan operasional pendidikan (BOP) antara lain: minimal memiliki siswa 60 orang, memiliki izin operasional, bangunan fisik, minimal memiliki 4 kelas, minimal memiliki 4 orang pengajar, usia madrasah minimal 2 tahun, tidak sedang mendapatkan bantuan dari instansi/ lembaga lain.

Adapun tujuan penelitian ini adalah Membangun sistem pendukung keputusan penerima bantuan operasional pendidikan madrasah menggunakan metode Multi Criteria Decision Making (MCDM) dan model Weighted Product Models (WPM) pada Kementerian Agama Kota Serang dengan program aplikasi Borland Delphi7, sebagai penerapan perkembangan teknologi, sehingga memudahkan untuk memberikan rekomendasi terhadap penetapan penerima bantuan operasional pendidikan (BOP) madrasah

\section{DASAR TEORI}

\section{A. Unified Modelling Language (UML)}

Menurut Munawar mengatakan UML adalah "salah satu alat bantu yang sangat handal di dunia pengembangan sistem yang berorientasi objek.

\section{B. Sistem Pendukung Keputusan (SPK)}

dan Ivanna (2012), Whitten menyatakan bahwa Sistem pendukung keputusan (Decision Support System/DSS) adalah suatu sistem informasi yang membantu mengidentifikasi kesempatan membuat keputusan atau menyediakan informasi untuk membantu pembuatan keputusan. 
Jurnal Sistem Informasi Vol- 1 No.1 2014

Dalam Handy (2011), Turban menyatakan, Sistem pendukung keputusan pada hakekatnya memiliki beberapa tujuan yaitu:

1) Membantu manajer dalam pengambilan keputusan atas masalah semi- terstruktur.

2) Memberikan dukungan atas pertimbangan manajer dan bukan untuk menggantikan fungsi manajer

3) Meningkatkan efektifitas keputusan yang diambil manajer lebih daripada perbaikan efisiensinya.

4) Kecepatan komputasi. Komputer memungkinkan para pengambil keputusan untuk melakukan banyak komputasi secara cepat dengan biaya yang rendah.

5) Dukungan kualitas. Komputer bisa meningkatkan kualitas keputusan yang dibuat, misalnya: semakin banyak data yang diakses, makin banyak juga alternatif yang bisa dievaluasi.

6) Mengatasi keterbatasan kognitif dalam pemrosesan dan penyimpanan

\section{Metode multi criteria decision making (MCDM)}

Dalam Ridho (2008), Yoon, K., et al. menyatakan Multi Criteria Decision Making (MCDM) merupakan teori yang membahas mengenai proses pengambilan keputusan yang mempertimbangkan banyak kriteria. Teori ini dapat dibagi menjadi dua cabang berdasarkan sifat dari alternative, yaitu:

1) Multi Attribute Decision Making (MADM):

Pada teori ini jumlah alternative dianggap terbatas dan sudah dapat dilihat sebelum proses pengambilan keputusan dilakukan.

2) Multi Objective Decision Making (MODM):

Pada teori ini jumlah alternatif dianggap tidak terbatas dan dirancang menggunakan data kontinu dengan model matematika.

\section{Weighted Product Model (WPM)}

Ada dua pendekatan yang dapat digunakan dalam menerapkan WPM. Pendekatan pertama adalah dengan menerapkan perbandingan secara berpasangan setiap alternatif, sementara pendekatan kedua adalah dengan perhitungan nilai setiap alternatif tanpa perbandingan berpasangan.

Pada pendekatan pertama, setiap dua alternatif akan dibandingkan secara berpasangan. Jika rasio perbandingan tersebut nilainya lebih besar dari 1 , maka alternatif pertama akan lebih dipilih daripada alternatif kedua. Persamaan yang digunakan untuk melakukan perbandingan ditunjukkan dalam persamaan dibawah. Misalkan alternatif Ak dan AL ingin dibandingkan, maka persamaannya adalah sebagai berikut :

$$
R\left(A_{K} / A_{L}\right)=\prod_{j=1}^{N}\left(a_{K_{j}} / a_{L j}\right)^{w_{j}}
$$

Sementara pada pendekatan kedua, nilai setiap alternatif akan dihitung secara terpisah dengan persamaan berikut :

$$
P\left(A_{K}\right)=\prod_{j=1}^{N}\left(a_{K j}\right)^{w_{j}}
$$

ISSN: 2406-7768

\section{HASIL DAN PEMBAHASAN}

\section{A. Analisa Input}

Dalam metode penelitian ini ada bobot dan kriteria yang dibutuhkan untuk menentukan penerima bantuan operasional pendidikan. Adapun kriterianya adalah: jumlah siswa, jumlah guru, kondisi bangunan, izin operasional, usia madrasah, jumlah kelas, dan bantuan sejenis.

\section{B. Analisa Output}

Keluaran yang dihasilkan dari penelitian ini adalah diambil dari jumlah nilai akhir lembaga yang memiliki nilai terbesar dibandingkan dengan nilai lembaga lain. Hasil akhir yang dikeluarkan berasal dari jumlah keseluruhan dari nilai setiap kriteria, karena dalam setiap kriteria memiliki nilai yang berbeda-beda

\section{Analisa uji Coba}

Pada proses uji coba ini menggunakan tiga data pegawai dengan menggunakan data atau kriteria yang sama akan tetapi memiliki bobot yang berbeda. Pada proses uji coba ini menggunakan tiga data lembaga dengan menggunakan data atau criteria

1) Menentukan Bobot nilai kriteria:

Dalam penelitian ini ada bobot dan kriteria yang dibu tuhkan untuk menentukan siapa yang akan terseleksi sebag ai penerima BOP.

Tabel 1.Kode dan Ketentuan Kriteria

\begin{tabular}{|c|c|}
\hline Kode kriteria & Ketentuan kriteria \\
\hline C1 & Jumlah Siswa \\
\hline C2 & Jumlah Guru \\
\hline C3 & Kondisi Bangunan \\
\hline C4 & Izin Operasional \\
\hline C5 & Usia Madrasah \\
\hline C6 & Jumlah Kelas \\
\hline C7 & Bantuan Sejenis \\
\hline
\end{tabular}

Dari kriteria tersebut akan ditentukan bobotnya.

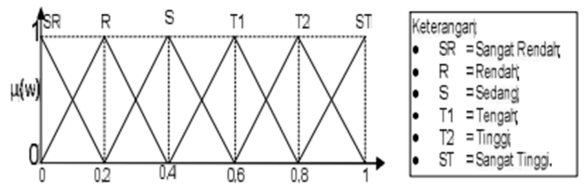

Dari masing-masing bobot tersebut, maka dibuat suatu var iabel yang akan dirubah kedalam bilangan fuzzy dengan $\mathrm{r}$ umus yaitu variabel ke-n/n-1.

1. Kriteria jumlah siswa

Tabel 2. Kriteria jumlah siswa

\begin{tabular}{|c|c|}
\hline Jumlah siswa & Nilai \\
\hline$<60$ & 0,33 \\
\hline$=60$ & 0,6 \\
\hline$>60$ & 1 \\
\hline
\end{tabular}


2. Kriteria jumlah guru

Tabel 3. Kriteria jumlah guru

\begin{tabular}{|c|c|}
\hline Jumlah guru & Nilai \\
\hline$<60$ & 0,33 \\
\hline$=60$ & 0,6 \\
\hline$>60$ & 1 \\
\hline
\end{tabular}

3. Kriteria kondisi bangunan

Tabel 4. Kriteria kondisi bangunan

\begin{tabular}{|c|c|}
\hline Kondisi bangunan & Nilai \\
\hline Rusak berat & 0,33 \\
\hline Rusak ringan & 0,6 \\
\hline Baik & 1 \\
\hline
\end{tabular}

\begin{tabular}{|l|l|}
\hline \multicolumn{2}{|l|}{ ID lembaga: 311236730228 } \\
\hline Nama lembaga: Nurul Huda \\
\hline Data & Nilai Data \\
\hline Jumlah murid & 63 \\
\hline Jumlah guru & 4 \\
\hline Kondisi bangunan & Baik \\
\hline Izin operasional & Memiliki izin operasional \\
\hline Usia madrasah & 17 tahun \\
\hline Jumlah kelas & 3 \\
\hline Bantuan sejenis & $\begin{array}{l}\text { Tidak } \\
\text { bantuan dari instansi lain }\end{array}$ \\
\hline
\end{tabular}

4. Kriteria izin operasional

Tabel 5. Kriteria izin operasional

\begin{tabular}{|c|c|}
\hline Izin operasional & Nilai \\
\hline Tidak & 0 \\
\hline Ya & 1 \\
\hline
\end{tabular}

5. Kriteria usia madrasah

Tabel 6. Kriteria usia madrasah

\begin{tabular}{|c|c|}
\hline Usia madrasah & Nilai \\
\hline$<2$ & 0 \\
\hline$=2$ & 0,25 \\
\hline$<5$ & 0,5 \\
\hline$<10>5$ & 0,75 \\
\hline$>10$ & 1 \\
\hline
\end{tabular}

6. Kriteria jumlah kelas

Tabel 7. Kriteria jumlah kelas

\begin{tabular}{|c|c|}
\hline Jumlah kelas & Nilai \\
\hline$<60$ & 0,33 \\
\hline$=60$ & 0,6 \\
\hline$>60$ & 1 \\
\hline
\end{tabular}

7. Kriteria bantuan sejenis

Tabel 8. Kriteria bantuan sejenis

\begin{tabular}{|c|c|}
\hline Bantuan sejenis & Nilai \\
\hline Ya & 0 \\
\hline Tidak & 1 \\
\hline
\end{tabular}

Tabel 9.Contoh profile lembaga

\begin{tabular}{|l|l|l|l|l|l|l|l|l|}
\hline No & Lembaga & C1 & C2 & C3 & C4 & C5 & C6 & C7 \\
\hline 1 & $\begin{array}{l}\text { Nurul } \\
\text { Huda }\end{array}$ & 63 & 4 & baik & Ya & $\begin{array}{l}17 \\
\text { thn }\end{array}$ & 3 & tidak \\
\hline 2 & $\begin{array}{l}\text { Al } \\
\text { Mujahidin }\end{array}$ & 46 & 4 & $\begin{array}{l}\text { Rusak } \\
\text { ringan }\end{array}$ & Ya & $\begin{array}{l}9 \\
\text { thn }\end{array}$ & 2 & tidak \\
\hline 3 & Al Ikhsan & 77 & 5 & $\begin{array}{l}\text { Rusak } \\
\text { ringan }\end{array}$ & Ya & $\begin{array}{l}7 \\
\text { thn }\end{array}$ & 4 & tidak \\
\hline
\end{tabular}

2) Menentukan nilai WPM

Proses penghitungan performasi ini dilakukan untuk setiap alternatif terhadap preferensi yang tergambarkan di profile lembaga. Setelah semua nilai performansi diperoleh maka tahap kedua adalah menghitung nilai wpm untuk setiap alternatif sehingga alternatif-alternatif terbaik dapat diperoleh. Rumus perhitungan nilai WPM untuk alternatif adalah sebagai berikut :

$\boldsymbol{A}_{\text {WPM }}^{\mathbf{i}}=\left(X_{\text {iJumlahMurid }}{ }^{\text {WJumlahMurid }}\right) . \quad$ WKondisiBangunan ${ }{ }^{W}$ JumlahGuru $).\left(X_{\text {iKondisiBangunan }}{ }^{\text {WKondisiBangunan }}\right)$.

$\left(X_{\text {iIzinOperasional WIzinOperasional }}\right) .\left(X_{\text {iUsiaMadrasah }}\right.$ WUsiaMadrasah )$.\left(X_{\text {iJumlahKelas }}^{\text {WJumlahKelas }}\right) .\left(X_{\text {iBantuanSejenis }}^{\text {WBantuanSejenis }}\right)$

Tabel Profile Lembaga Nurul Huda

\begin{tabular}{|l|l|}
\hline \multicolumn{2}{|l|}{ ID lembaga: 311236730177 } \\
\hline Nama lembaga: Al Ikhsan \\
\hline Data & Nilai Data \\
\hline Jumlah murid & 77 \\
\hline Jumlah guru & 5 \\
\hline Kondisi bangunan & Rusak ringan \\
\hline Izin operasional & Ya / memiliki izin operasional \\
\hline Usia madrasah & 7 tahun \\
\hline Jumlah kelas & 4 \\
\hline Bantuan sejenis & $\begin{array}{l}\text { Tidak mendapatkan bantuan dari } \\
\text { instansi lain }\end{array}$ \\
\hline
\end{tabular}


Jurnal Sistem Informasi Vol- 1 No.1 2014

Tabel 11 Nilai Performansi dan WPM

\begin{tabular}{|c|c|}
\hline Kriteria & Nilai performansi \\
\hline Jumlah murid & 0,6 \\
\hline Jumlah guru & 1 \\
\hline Kondisi bangunan & 1 \\
\hline Izin operasional & 1 \\
\hline Usia madrasah & 0,33 \\
\hline Jumlah kelas & 1 \\
\hline Bantuan sejenis & $\begin{array}{l}\text { Nilai WPM }=1^{1 / 7} * 0,6^{1 / 7} * 1^{1 / 7} * 1^{1 / 7} * 1^{1 / 7} * 0,33^{1 / 7} * 1^{1 / 7} \\
=1 * 0,9295 * 1 * 1 * 1^{1 / 7} \\
0,79534\end{array} 1^{*}=0,7932353 \sim$ \\
0,7932
\end{tabular}

Tabel 12 Profile Lembaga Al Mujahidin

\begin{tabular}{|l|l|}
\hline \multicolumn{2}{|l|}{ ID lembaga: 311236730214 } \\
\hline Nama lembaga: Al Mujahidin \\
\hline Data & Nilai Data \\
\hline Jumlah murid & 46 \\
\hline Jumlah guru & 4 \\
\hline Kondisi bangunan & Rusak ringan \\
\hline Izin operasional & $\begin{array}{l}\text { Ya / memiliki izin } \\
\text { operasional }\end{array}$ \\
\hline Usia madrasah & 9 tahun \\
\hline Jumlah kelas & 2 \\
\hline Bantuan sejenis & $\begin{array}{l}\text { Tidak } \\
\text { bantuan dari instansi lain }\end{array}$ \\
\hline
\end{tabular}

Tabel 13 Nilai Performansi dan WPM

\begin{tabular}{|c|c|}
\hline Kriteria & Nilai performansi \\
\hline Jumlah murid & 0,33 \\
\hline Jumlah guru & 0,6 \\
\hline Kondisi bangunan & 0,6 \\
\hline Izin operasional & 1 \\
\hline Usia madrasah & 0,75 \\
\hline Jumlah kelas & 0,33 \\
\hline Bantuan sejenis & 1 \\
\hline \multicolumn{2}{|c|}{$\begin{array}{l}\text { Nilai WPM }=0,33^{1 / 7} * 0,6^{1 / 7} * 0,6^{1 / 7} * 1^{1 / 7} * 0,75^{1 / 7} \\
* 0,33^{1 / 7} * 1^{1 / 7}=0,8534 * 0,9295 * 0,9295 * 1 * \\
0,9597 * 0,8534 * 1=0,6038645 \sim 0,6039\end{array}$} \\
\hline
\end{tabular}

Tabel 14 Profile Lembaga Al Ikhsan

\begin{tabular}{|l|l|}
\hline \multicolumn{2}{|l|}{ ID lembaga: 311236730177 } \\
\hline Nama lembaga: Al Ikhsan \\
\hline Data & Nilai Data \\
\hline Jumlah murid & 77 \\
\hline Jumlah guru & 5 \\
\hline Kondisi bangunan & Rusak ringan \\
\hline Izin operasional & Ya / memiliki izin operasional \\
\hline Usia madrasah & 7 tahun \\
\hline Jumlah kelas & 4 \\
\hline Bantuan sejenis & $\begin{array}{l}\text { Tidak mendapatkan bantuan dari } \\
\text { instansi lain }\end{array}$ \\
\hline
\end{tabular}

ISSN: 2406-7768

Tabel 15 Nilai Performansi Dan WPM

\begin{tabular}{|c|c|}
\hline Kriteria & Nilai performansi \\
\hline Jumlah murid & 1 \\
\hline Jumlah guru & 1 \\
\hline Kondisi bangunan & 0,6 \\
\hline Izin operasional & 1 \\
\hline Usia madrasah & 0,75 \\
\hline Jumlah kelas & 0,6 \\
\hline Bantuan sejenis & 1 \\
\hline $\begin{array}{l}\text { Nilai WPM }=1^{1 / 7} * 1^{1 / 7} * 0,6^{1 / 7} * 1^{1 / 7} * 0,75^{1 / 7} * \\
0,6^{*} 1^{1 / 7}=1 * 1 * 0,9295 * 1 * 0,9597 * 0,9295 * \\
1=0,8291522 \sim 0,8292\end{array}$ \\
\hline
\end{tabular}

\section{Hasil Analisa Uji Coba}

Dari hasil uji coba menggunakan tiga data lembaga yang memenuhi kriteria pada perhitungan WPM tersebut adalah madrasah Al Ikhsan dengan nilai 0,8291.

\section{E. Kesimpulan}

1) Sistem penyeleksian penerima BOP yang terjadi di kemenag pada saat ini masih dilakukan secara manual sehingga proses penyeleksian belum dapat berjalan dengan tepat waktu, tepat guna dan tepat sasaran

2) Penggunaan metode Multi Criteria Decision Making (MCDM) dan model Weight Product Models (WPM) dapat menentukan bobot berdasarkan kriteria penilaian penyeleksi dengan alternatif kecocokan berdasarkan prioritas pengambil keputusan.

3) Kriteria yang diperhatikan dalam pemberian rekomendasi pada permasalahan proses seleksi penerima BOP meliputi jumlah siswa, jumlah guru, jumlah kelas, usia madrasah, izin operasional, kondisi bangunan, dan tidak mendapatkan bantuan dari instansi lain. Semua kriteria tersebut menjadi atribut di profile lembaga.

4) Penggunaan sebuah program komputer dengan Software Borland Delphi7 dalam sistem pendukung keputusan dapat memberikan sebuah proses nilai akhir yang lebih akurat dan cepat.

\section{DAFTAR PUSTAKA}

[1] Handy, T.P., 2011. "Sistem Pendukung Keputusan Pemilihan Mobil Menggunakan Metode Simple Multi Attribute Rating Technique (SMART)", Tugas Akhir, Fakultas Matematika Dan Ilmu Pengetahuan Alam, Universitas Sumatera Utara, Medan

[2] Akhiro, R. (2008) "Studi Multi Criteria Decision Making (MCDM) untuk Recommender System Bursa Tenaga Kerja", Tesis Program Studi Magister Informatika, Sekolah Teknik Elektro dan Informatika, Institut Teknologi Bandung, Bandung.

[3] Eniyati, S. (2011) "Perancangan Sistem Pengambilan Keputusan Untuk Penerimaan Beasiswa Dengan Metode SAW (Simple Additive 
Weighting)", Jurnal Teknologi Informasi DINAMIK, ISSN:0854-9524, Vol. 16. No. (2), Hal. 171-176.

[4] Lestari, S (2013) "Penerapan Metode Weighted Product Model Untuk Seleksi Calon Karyawan", Jurnal Sistem Informasi, ISSN Print : 20851588, Vol. 5. No. (1), Hal. 540-545

[5] Septiani, W. dan Ivanna, "Perancangan Sistem Pendukung Keputusan untuk Penilaian Prestasi Belajar Siswa Sekolah Dasar Pusaka Bangsa", Jurnal Teknik Industri, ISSN:1411-6340, Hal. 56-64.

[6] Munawar. (2005). Pemodelan Visual dengan UML. Jakarta : Graha Ilmu 